\title{
PENERAPAN IOT (INTERNET OF THING) UNTUK SISTEM MONITORING JEMAAH MASJID SESUAI PROTOKOL KESEHATAN TERHADAP VIRUS COVID-19 BERBASIS ARDUINO
}

\author{
Andrew Janeananto Sanjaya, Yosep Agus Pranoto, Febriana Santi Wahyuni \\ Program Studi Teknik Informatika S1, Fakultas Teknologi Industri \\ Institut Teknologi Nasional Malang, Jalan Raya Karanglo km 2 Malang, Indonesia \\ 1718114@scholar.itn.ac.id
}

\begin{abstract}
ABSTRAK
Dalam New Normal, aktivitas seperti beribadah di Masjid memiliki protokol kesehatan. Namun pada kenyatannya masih banyak Masjid yang belum menjalankan maupun kurang mematuhi protokol kesehatan. Hal ini tentu saja dapat berakibat fatal karena Masjid bisa menjadi salah satu tempat penyebaran COVID-19 jika protokol kesehatan tidak dijalankan dengan baik oleh para jemaah maupun para pengurus Masjid. Masjid bisa menjadi tempat penyebaran COVID-19 karena kurangnya kesadaran untuk menjaga jarak dan kurang menjaga kesehatan tubuh.

Atas masalah yang telah diuraikan maka sistem monitoring pada Masjid berbasis arduino dapat menjadi solusi untuk meningkatkan kesadaran akan protokol kesehatan di dalam Masjid. Sistem ini dilengkapi dengan sensor jarak dan sensor suhu agar jemaah dapat terkontrol dalam menjaga jarak dan suhunya serta terdapat bilik disinfektan untuk menyeprotkan disinfektan kepada para jemaah.

Hasil dari penelitian ini berupa simulasi Masjid yang dilengkapi dengan sensor suhu yang memiliki tingkat keakuratan 98,82\% dan jarak yang dapat bekerja dengan baik dengan tingkat keakuratan 93,33\% dan juga informasi berupa jumlah jemaah dan jarak shaf sholat yang dapat dilihat secara real time pada lcd dan web, serta saat jemaah masuk maka semportan disinfektan akan menyala dan jika masjid penuh maka pagar akan tertutup otomatis.
\end{abstract}

Kata Kunci : COVID-19, Protokol Kesehatan, Arduino, IoT (Internet of Things)

\section{PENDAHULUAN}

COVID-19 merupakan sebuah jenis penyakit menular yang disebabkan oleh virus corona yang baru saja ditemukan pada tahun 2019. COVID-19 tidak dikenal sebelum menyebarnya wabah ini di Wuhan, Tiongkok pada bulan Desember tahun 2019. COVID19 ini telah menjadi pandemi yang telah menimpa dan terjadi pada negara-negara di seluruh dunia. [1]

Masih belum diketahui kapan pandemi COVID19 akan berakhir, sehingga masyarakat diharapkan dapat beradaptasi dengan mengikuti gaya hidup yang baru (New Normal). Masyarakat harus mampu dan mau mematuhi protokol kesehatan COVID-19. Oleh karena itu diperlukan kerja sama di antara masyarakat dan pemerintah agar Bersama-sama mengurangi tingkat penyebaran COVID-19. Protokol kesehatan untuk mencegah dan mengendalikan COVID-19 adalah selalu mencuci tangan, menghindari sentuhan pada bagian wajah, menerapkan tata cara saat bersin dan batuk, selalu memakai masker, menjaga jarak, isolasi mandiri saat merasa kurang sehat, menjaga kesehatan dan juga membersihkan diri dan berganti pakaian saat telah kembali ke rumah setelah melakukan kegiatan dari luar rumah. [2]

Dalam New Normal, aktivitas sudah dapat dilakukan kembali seperti beribah di tempat ibadah. Dalam melaksanakan aktivitas tersebut tentu saja harus mengikuti protokol kesehatan. Protokol kesehatannya antara lain menjaga kebersihan lantai masjid, menjaga kebersihan alas shalat, menjaga kebersihan tempat wudhu, membawa sajadah sendiri dan menghimbau agar para jama'ah yang kurang sehat untuk shalat di rumah. [3]

Pada kenyatannya masih banyak Masjid yang belum menjalankan maupun kurang mematuhi protokol kesehatan. Hal ini tentu saja dapat berakibat fatal karena kurangnya pencegahan dari COVID-19 pada Masjid. Masjid-masjid bisa menjadi salah satu tempat penyebaran COVID-19 jika protokol kesehatan tidak dijalankan dengan baik oleh para jamaah maupun pengurus Masjid.

Oleh karena itu penulis bermaksud membuat alat monitoring jarak dan suhu pada Masjid berbasis arduino untuk meningkatkan kesadaran akan protokol kesehatan di dalam Masjid. Hal ini dapat memudahkan pengurus dalam pengecekan jemaah yang ada pada masjid apakah sudah menjaga jarak atau belum, pengurus masjid juga dapat memeriksa suhu tanpa harus bertatap langsung dengan jemaah. Jemaah juga dapat dimudahkan untuk saling menjaga jarak, serta jemaah dapat mengetahui apakah dirinya cukup sehat untuk beribadah di Masjid. Namun kesadaran diri sendiri untuk menjaga kesehatan sendiri maupun bersama harus ditanamkan oleh masyarakat terutama pada jamaah yang pergi ke Masjid. 


\section{TINJAUAN PUSTAKA}

\subsection{Penelitian Terdahulu}

Ridwan (2017) pada penelitian dengan judul "Rancang Bangun Sistem Monitoring Tempat Parkir Berbasis Arduino (Smart Parking)". Tujuan penelitian ini yaitu agar pengemudi tidak perlu lagi membuang tenaga dan waktu untuk berkeliling mencari tempat parkir yang kosong. Terdapat persamaan dari penelitian ini adalah penggunakan sistem deteksi jarak, yang membedakan antara sistem yang dibuat Ridwan adalah sistem yang dibuat adalah sistem Smart Parking.[1]

Bakhtiyar (2017) pada penelitian selanjutnya dengan judul "Aplikasi Sensor Ultrasonik Untuk Deteksi Posisi Jarak Pada Ruang Menggunakan Arduino Uno". Tujuan dari penelitian ini adalah memecahkan masalah pendeteksian jarak pada objek atau ruang, sehingga sensor ultrasonik yang digunakan dapat mendeteksi jarak antar objek secara akurat. Adapun persamaan yaitu menggunakan sensor yang sama yaitu sensor ultrasonik HC SR04 yang menjadi perbedaannya adalah penulis menggunakan hcrf sebagai salah satu sensor untuk mendeteksi jarak pada jemaah sedangkan Bakhtiyar menggunakan sensor HC SR04 saja untuk meningkatkan ke akuratan dari sensor ultrasonik.[5]

Suryani (2018) pada penelitian selanjutnya dengan judul "Sistem Monitoring Detak Jantung dan Suhu Tubuh Menggunakan Arduino". Tujuan dari penelitian ini adalah meningkatkan pelayanan rumah sakit atau puskesmas dalam memantau kesehatan pasien, mengurangi misdiagnosis, mempercepat hasil pemeriksaan, dan mendukung aplikasi dari pelayanan kesehatan secara profesional yang telah melibatkan berbagai macam disiplin ilmu. Adapun persamaan yaitu bertujuan untuk mengukur suhu tubuh namun dengan perbedaan sensor yaitu DS18b20 sedangkan sensor yang penulis pakai adalah MLX90614. [6]

Syah Alam (2019) pada penelitian selanjutnya dengan judul "Rancang Bangun Sistem Penyiraman Otomatis untuk Tanaman Berbasis Arduino dan Kelembaban Tanah". Tujuan penelitian ini yaitu untuk membuat sistem penyiraman otomatis pada tanaman dengan kondisi dari kelembaban tanah yang ditenagai dengan panel surya. Adapun persamaan yaitu bertujuan untuk membuat output atau controling sesuai dengan kondisi yang telah ditentukan. [7]

Marfin (2020) pada penelitian selanjutnya dengan judul "Pelatihan Pembuatan dan Penggunaan Hand Sanitizer Otomatis mencegah Covid-19 dan Santunan Anak Yatim Dhuafa". Tujuan penelitian ini adalah untuk membuat dan melatih masyarakat yang ada pada jalan H. Rean RT.007/05, Kel. Benda Baru, Kec. Pamulang, Tanggerang Selatan dalam penggunaan hand sanitizer otomatis. Adapun persamaan yaitu bertujuan untuk membuat penyemprot otomatis menggunakan sensor dimana pada penelitian ini digunakan sensor HC-SR04 dan penulis membuat penyemprot disinfektan menggunakan push button. [8]

\subsection{Arduino Mega}

Board Arduino Mega merupakan Board Arduino yang menggunakan kontroler berupa kontroler ATmega 2560. Arduino memiliki cukup banyak pin, yaitu pin I/O sebanyak 54 digital pin $I / O$ (pin Input / Output), 15 buah pin $I / O$ yang dapat digunakan sebagai PWM (Pulse With Modulation), 16 buah pin input analog, dan 4 UART. Arduino Mega dilengkapi dengan kristal $16 \mathrm{Mhz}$ yang relatif mudah untuk penggunaan yang sederhana. Pengunaannya hanya dengan menghubungkan catu daya dari USB ke PC / Laptop atau menggunakan adaptor DC 7-12 V melalui jack DC. [8]

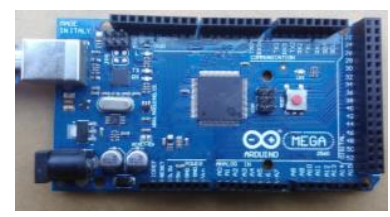

Gambar 1 Arduino Mega

\subsection{NodeMCU}

NodeMCU adalah sebuah board yang berbasis IoT (Internet of Thing) open source. NodeMCU terdiri dari perangkat keras berupa SOC (System On Chip) ESP8266 dari ESP8266 yang diproduksi oleh Esperessif System. NodeMCU dapat disimulasikan sebagai arduino yang sudah terhubung langsung dengan ESP8622. NodeMCU telah memaketkan ESP8266 ke dalam board yang sudah terintergrasi dengan berbagai fungsi sebagaimana seharusnya mikrokontroller, akses terhadap wifi, dan komunikasi $U S B$ to serial, sehingga hanya diperlukan satu buah kabel data USB. Sumber utama NodeMCU yaitu ESP8266 khusunya seri ESP-12 yang termasuk ESP$12 \mathrm{E}$, jadi fungsi-fungsi yang dimiliki oleh NodeMCU kurang lebih sama dengan ESP-12. Fitur NodeMCU meliputi 10 buah pin digital dari pin D0 sampai dengan pin D10, PWM, dan Antarmuka I2C dan SPI. [9]

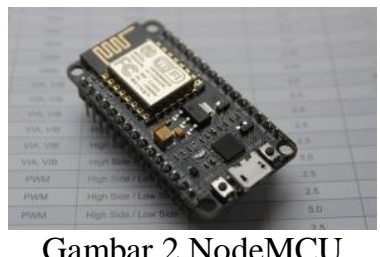

\subsection{Push Button}

Push button merupakan komponen elektronik yang dapat menentukan mengalir atau tidaknya arus pada rangkaian proyek Arduino. Ketika push button ditekan maka rangakaian akan menjadi bernilai $\mathrm{HIGH}$ serta menghantarkan arus. Pada saat yang sama, jika dilepaskan maka rangkaian akan menjadi bernilai LOW serta memutus arus. Push button memiliki tipe yang tidak mengunci, sehingga akan kembali lagi ke posisi semula ketika ditekan. Untuk penggunaan dari push button yaitu untuk tombol reset, select, input 
nilai, menyalakan lampu dan masih banyak lagi kegunaan push button lainnya. [10]

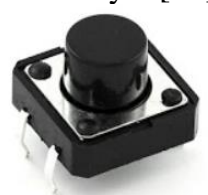

Gambar 3 Push Button

\subsection{HC-SR04}

Sensor ultrasonik adalah sebuah sensor yang dapat bekerja menggunakan prinsip pemantulan dari gelombang suara. Sensor bekerja dengan mengirimkan gelombang suara, jika gelombang suara tersebut mengenai suatu benda maka gelombang tersebut akan dipantulkan dan diterima oleh sensor tersebut. Sensor ulraksonik digunakan untuk mendeteksi ada tidaknya objek tertentu di depannya. Pada HC-SR04, terdapat sepasang transducer yang salah satunya berfungsi sebagai transmitter atau pemancar dimana tugasnya dimaksudkan untuk mengubah sinyal elektrik menjadi sinyal pulsa gelombang suara ultrasonik dengan frekuensi sebesar $40 \mathrm{KHz}$, dan yang lainnya berfungsi sebagai receiver atau penerima yang bertugas untuk dapat menerima sinyal gelombang suara ultrasonic yang dihasilkan oleh transmitter. [11]

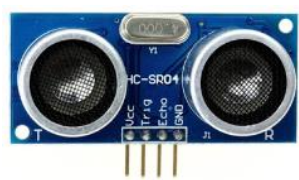

Gambar 4 HC-SR04

\subsection{Motor Servo}

Motor Servo adalah motor yang menggunakan sistem closed loop. Sistem ini digunakan untuk mengontrol akselerasi dan kecepatan pada motor dengan keakuratan atau presisi yang tinggi. Motor servo juga biasanya digunakan untuk mengubah energi listrik menjadi energi mekanik melalui interaksi dua medan magnet permanen. Motor bertindak sebagai penggerak roda gigi sehingga dapat memutar potensiometer dan poros keluarannya secara bersamaan. Potensiometer atau encoder digunakan sebagai sensor yang dapat memberikan sinyal umpan balik ke sistem kontrol untuk menentukan posisi target. Jika sistem kontrol mendeteksi posisi target pada motor servo sudah benar, putaran secara otomatis berhenti. [12]

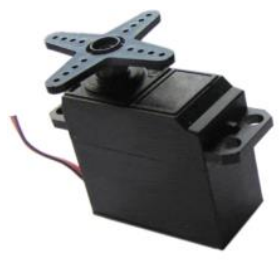

Gambar 5 Motor Servo

\subsection{MLX90614}

Sensor GY-906 MLX90614 atau MLX90614 adalah sensor yang dipergunakan untuk mengukur suhu dengan menggunakan radiasi gelombang infrared atau inframerah. Sensor MLX90614 sendiri dirancang dengan khusus agar dapat mendeteksi energi radiasi inframerah dan juga telah dirancang secara otomatis sehingga dapat dikalibrasikan dengan energi radiasi inframerah dalam skala suhu temperature tersebut. [13]

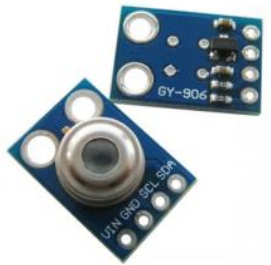

Gambar 6 MLX90614

\section{METODE PENELITIAN}

\subsection{Blok Diagram Sistem}

Blok diagram adalah diagram dari sebuah sistem, pada blok diagram menunjukkan bahwa sensor ultrasonik digunakan pada bagian dalam masjid untuk menjaga jarak antar shaf dan sensor suhu dan button digunakan untuk mengaktifkan serta mengecek suhu jamaah yang ingin shalat ke masjid. Dimana hal ini dapat dipermudah dengan pengurus masjid yang berada di ruang monitor, sehingga dapat menjangkau area masjid dan luar masjid dengan cepat. Karena dapat mengecek melalui website dengan suara dari bilik disinfektan serta pagar yang dapat terbuka dan tertutup sendiri dengan motor servo. Proses kerja pada alat ini di tunjukkan pada Gambar 7.

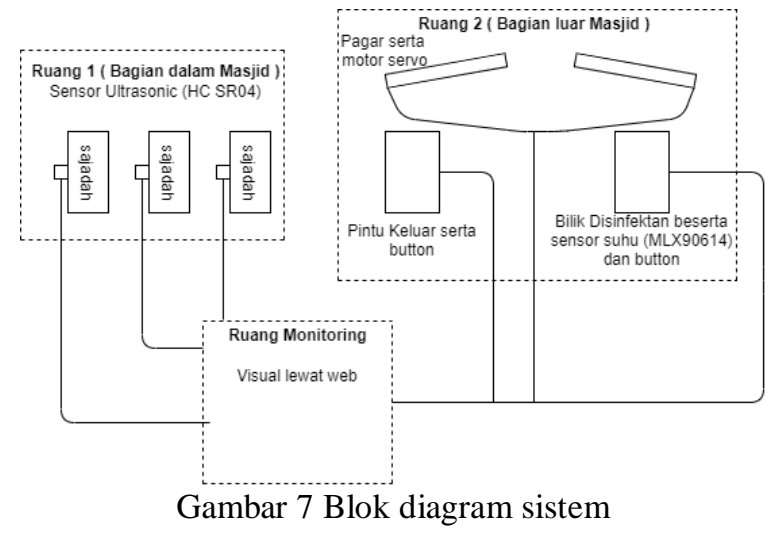

\subsection{Flowchart}

Flowchart sistem ini menjelaskan proses berjalananya aplikasi seperti ditunjukkan pada Gambar 3. 


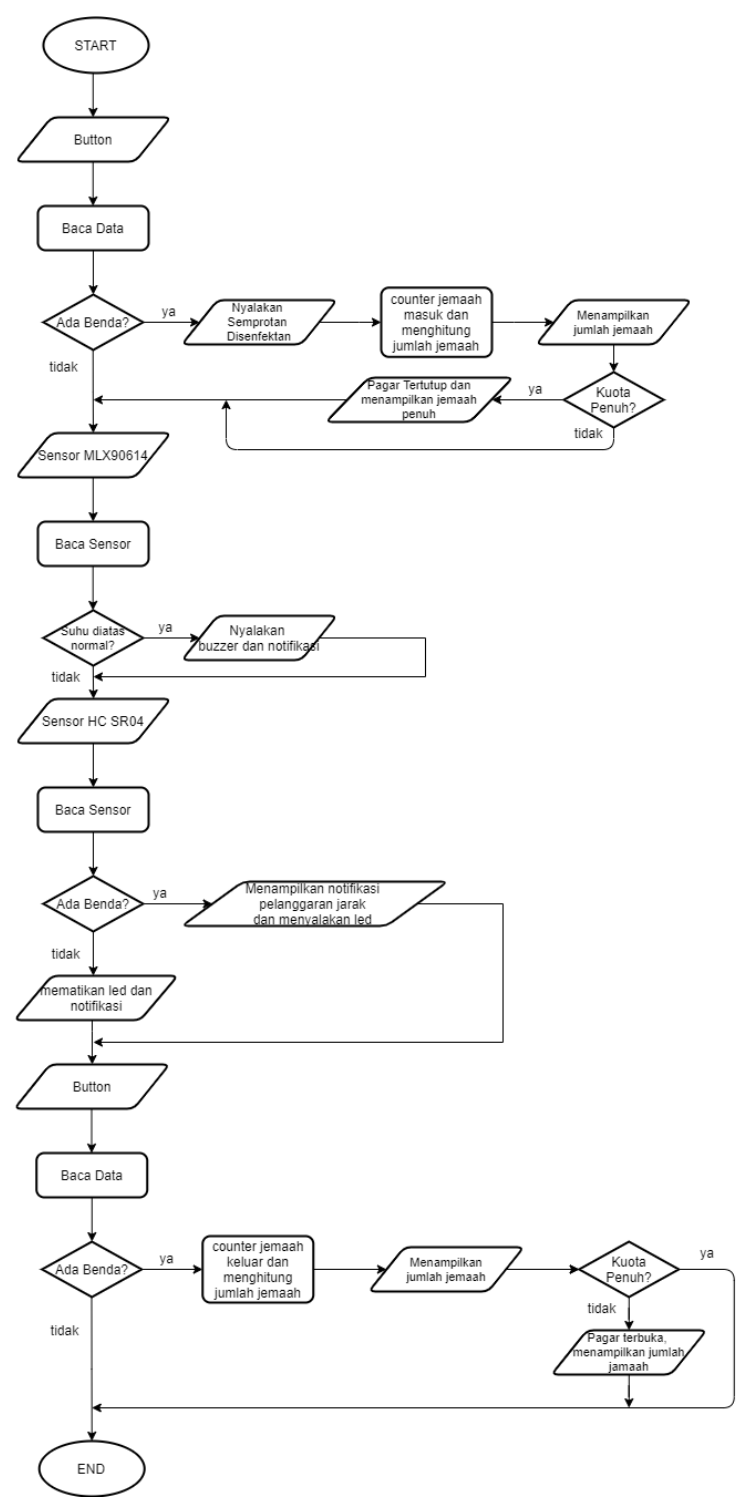

Gambar 8 Flowchart Sistem

Berdasarkan flowchart pada Gambar 8, button pertama akan mendeteksi jemaah yang masuk dan juga mengaktifkan semprotan disinfektan. Jika jumlah jemaah telah terisi sesuai kapasitas masjid, maka pagar akan tertutup. Selanjutnya sensor suhu mendeteksi suhu dan mengecek apakah jemaah yang datang memiliki suhu tubuh yang normal atau lebih tinggi. Jika lebih tinggi maka buzzer akan menyala dan notifikasi suhu akan muncul pada web. Selanjutnya sensor ultraksonik digunakan untuk mengecek apakah terdapat jemaah yang menempati ruang jarak pada setiap shaf sholat. Terakhir pada pintu keluar terdapat button kedua dimana button ini digunakan untuk menghitung jumlah jemaah yang keluar. Jika kondisi masjid penuh tidak lagi dipenuhi maka pagar masjid akan terbuka.

\subsection{Flowchart Sistem}

a. DFD Level 0

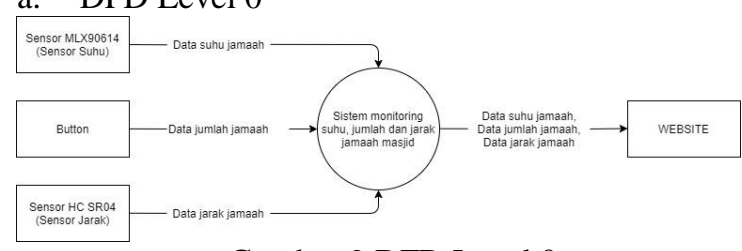

Gambar 9 DFD Level 0

b. DFD Level 1

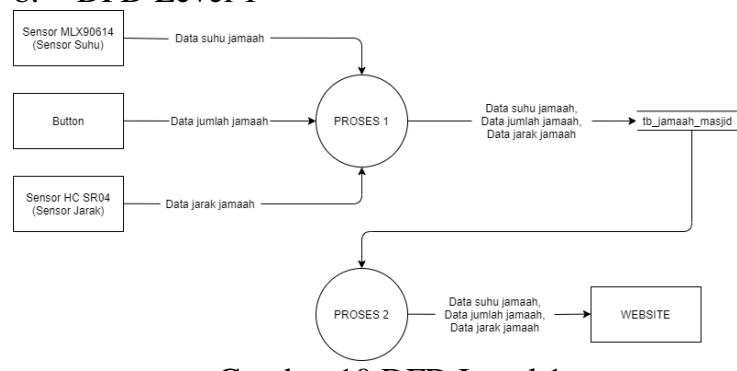

Gambar 10 DFD Level 1

\section{HASIL DAN PEMBAHASAN}

Pada Hasil dan Pembahasan akan diuraikan proses perancangan dan hasil pengujian sistem yang telah dibuat.

\subsection{Hasil Sistem}

\subsubsection{Tampilan Web}

Pada tampilan website ini ditampilkan halaman utama monitoring yang menampilkan informasi jarak pada setiap shaf sholat dan suhu jemaah terakhir yang masuk.
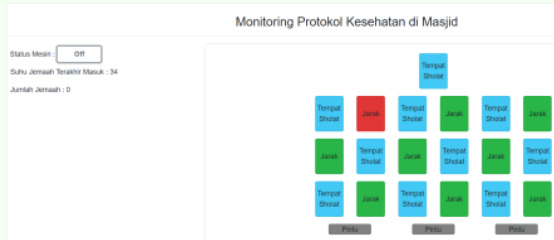

Gambar 11 tampilan web

Pada gambar 11 tampilan pada website menampilkan informasi suhu jemaah terakhir yang masuk ke Masjid dan informasi jumlah jemaah yang masuk dibandingkan dengan jumlah kapasitas jemaah Masjid yang tersedia. Tampilan jarak antar shaf juga diberikan informasi, jika jarak tidak sesuai dengan kondisi maka tempat jarak akan berubah warna menjadi merah dan akan kembali hijau jika kondisi jarak sudah terpenuhi lagi. Tampilan shaf sholat juga telah disesuaikan dengan prototipe Masjid bagian dalam dimana susunan shaf dan jarak telah disesuaikan, bagian pintu juga sudah disamakan dengan posisi asli dari prototipe masjid.

\subsubsection{Hasil Jemaah Masuk}

Pengimplementasian ini dilakukan bertujuan untuk melihat apakah alat dapat berjalan dengan baik dan dapat dijalankan dengan benar sesuai dengan yang diharapkan 


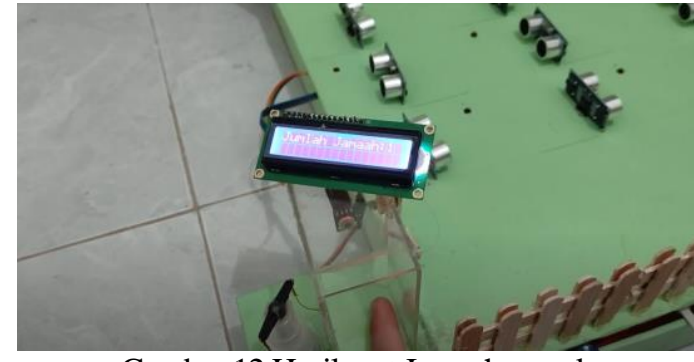

Gambar 12 Hasil saat Jemaah masuk

Pada gambar 12 dapat dilihat bahwa pada bilik disinfektan, papan injak atau button dapat berjalan dengan baik saat ditekan. Saat button ditekan, pada layar $l c d$ akan menampilkan jumlah jemaah yang telah masuk dan juga menyemprotkan disinfektan pada bilik.

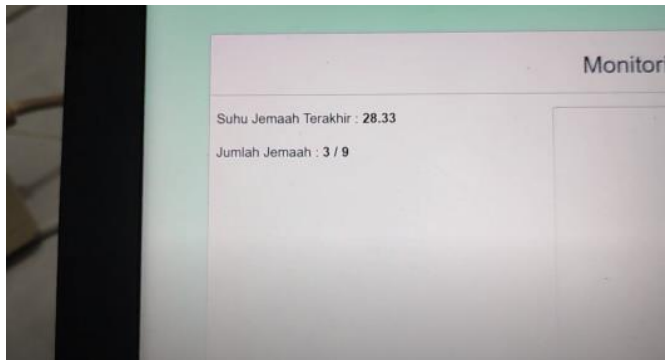

Gambar 13 Tampilan jumlah jemaah dan suhu pada web

Pada web dapat ditampilkan jumlah dan suhu jemaah. Data jumlah dan suhu ditampilkan secara real time.

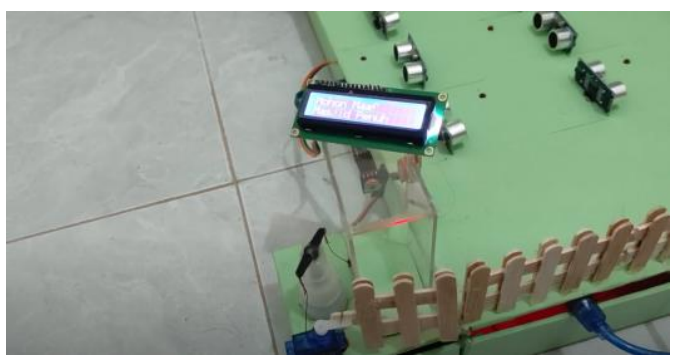

Gambar 14 Tampilan lcd saat masjid penuh

Gambar 14 menampilkan notifikasi "Mohon Maaf Masjid Penuh"pada lcd jika batas kuota Masjid telah terpenuhi.

\subsubsection{Hasil Jarak pada Shaf Sholat}

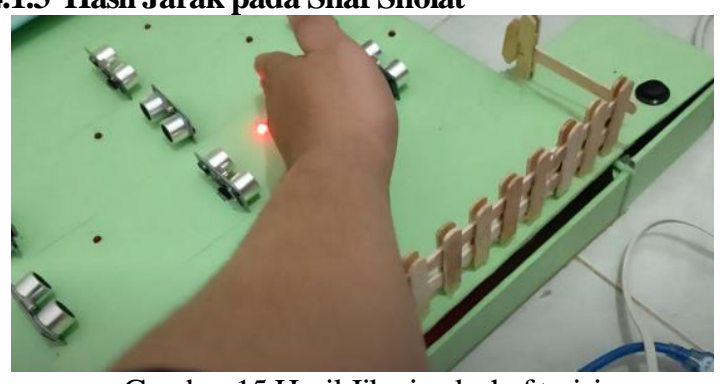

Gambar 15 Hasil Jika jarak shaf terisi

Gambar 15 menampilkan hasil berupa led menyala saat jarak terisi. Selain led menyala, buzzer juga akan menyala untuk memberitahukan jemaah bahwa ada protokol atau jarak yang dilanggar.

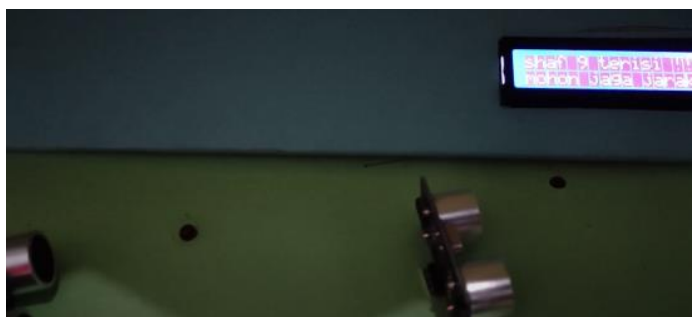

Gambar 16 tampilan lcd saat jarak terisi

Gambar 16 menampilkan lcd bertuliskan "shaf 2 terisi !! mohon jaga jarak". Tampilan ini tergantung pada shaf mana yang terbaca jaraknya. Jika pada jarak shaf maka akan menampilkan shaf 2 , begitu pula dengan shaf lainnya.

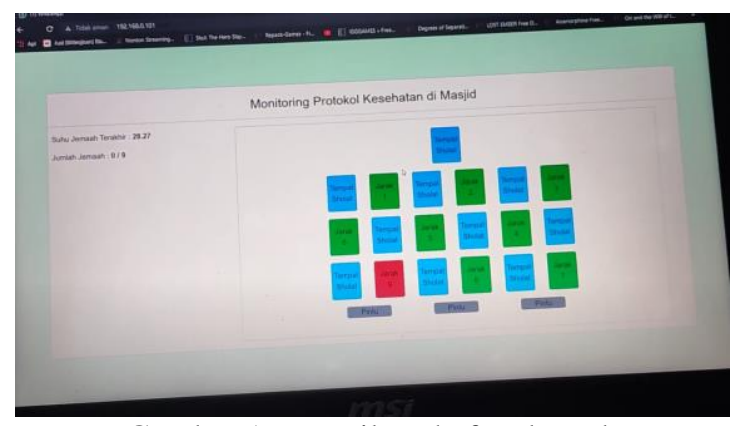

Gambar 17 tampilan shaf pada web

Gambar 17 menampilkan shaf-shaf yang ada pada masjid. Jika terdapat jarak yang dibaca, maka pada tampilan web akan menampilkan notifikasi berupa mengubah warna jarak menjadi merah, jika tidak ada jarak yang terbaca maka tampilan akan berwarna hijau.

\subsection{Pengujian}

\subsubsection{Pengujian Website}

Pengujian ini dilakukan untuk mengetahui respon terhadap beberapa web browser. Hasil uji dari web browser dapat dilihat pada tabel 1

Tabel 1 pengujian Website (Halaman Utama)

\begin{tabular}{|l|l|c|c|}
\hline No & \multicolumn{1}{|c|}{ Fungsi Yang Diuji } & Microsoft Edge & Google Chrome \\
\hline 1 & Suhu & $\checkmark$ & $\checkmark$ \\
\hline 2 & Jarak 1 & $\checkmark$ & $\checkmark$ \\
\hline 3 & Jarak 2 & $\checkmark$ & $\checkmark$ \\
\hline 4 & Jarak 3 & $\checkmark$ & $\checkmark$ \\
\hline 5 & Jarak 4 & $\checkmark$ & $\checkmark$ \\
\hline 6 & Jarak 5 & $\checkmark$ & $\checkmark$ \\
\hline 7 & Jarak 6 & $\checkmark$ & $\checkmark$ \\
\hline 8 & Jarak 7 & $\checkmark$ & $\checkmark$ \\
\hline 9 & Jarak 8 & $\checkmark$ & $\checkmark$ \\
\hline 10 & Jarak 9 & $\checkmark$ & $\checkmark$ \\
\hline 11 & Jumlah Jemaah & & $\checkmark$ \\
\hline
\end{tabular}


Tabel 1 Merupakan hasil pengujian yang dilakukan dengan membandingkan penggunaan web pada browser microsft edge dan google chrome. Hasil pengujian yang dilakukan berhasil menampilkan seluruh informasi yang ada dan dapat berjalan dengan baik pada browser microsoft edge dan google chrome.

\subsubsection{Pengujian Sensor MLX90614}

Pengujian menggunakan sensor MLX90614 yang berfungsi untuk mengetahui suhu jemaah masjid. Sensor diujikan untuk mengetahui tingkat error pada sensor MLX90614. Hasil pengujian sensor MLX90614 ditunjukkan pada tabel 2

Tabel 2 Hasil Pengujian Sensor MLX90614

\begin{tabular}{|c|c|c|c|c|}
\hline Objek & Jarak (cm) & MLX90614 $\left({ }^{\circ} \mathbf{C}\right)$ & Thermal Gun $\left({ }^{\circ} \mathbf{C}\right)$ & Error (\%) \\
\hline \multirow{2}{*}{$\begin{array}{l}\text { Manusia } \\
\text { (dahi) }\end{array}$} & 1 & 36,7 & 36,3 & 1,1 \\
\cline { 2 - 5 } & 3 & 36,0 & 36,3 & 0,8 \\
\cline { 2 - 5 } & 5 & 35,7 & 36,0 & 0,8 \\
\hline \multirow{2}{*}{$\begin{array}{l}\text { Manusia } \\
\text { (tangan) }\end{array}$} & 1 & 36,5 & 36,1 & 1,1 \\
\cline { 2 - 5 } & 3 & 35,6 & 36,1 & 1,4 \\
\cline { 2 - 5 } & 5 & 35,5 & 36,2 & 1,9 \\
\hline \multicolumn{5}{|c|}{ Total Error } \\
\hline \multicolumn{5}{|c|}{} \\
\cline { 2 - 5 }
\end{tabular}

Dari tabel 2 dapat dilihat bahwa pengujian pada bagian dahi dan tangan menggunakan sensor MLX90614 yang telah dikalibrasi memiliki selisih error $1,18 \%$ dibandingkan dengan thermal gun yang digunakan.

\subsubsection{Pengujian Sensor HC-SR04}

Pengujian menggunakan sensor HC-SR04 yang berbeda untuk mengetahui tingkar error pada setiap sensor HC-SR04 yang digunakan. Hasil pengujian sensor HCSR04 dapat dilihat pada tabel 3

Tabel 3 Hasil Pengujian Sensor HC-SR04

\begin{tabular}{|c|c|c|c|}
\hline HC-SR04 & $\begin{array}{c}\text { Pengukuran Sensor } \\
\text { (cm) }\end{array}$ & $\begin{array}{l}\text { Pengukuran } \\
\text { Manual (cm) }\end{array}$ & Error (\%) \\
\hline \multirow[t]{2}{*}{1} & 100 & 100 & 0 \\
\hline & 80 & 80 & 0 \\
\hline \multirow[t]{2}{*}{2} & 101 & 100 & 1 \\
\hline & 78 & 80 & 2,5 \\
\hline \multirow[t]{2}{*}{3} & 100 & 100 & 0 \\
\hline & 79 & 80 & 1,25 \\
\hline \multirow[t]{2}{*}{4} & 99 & 100 & 1 \\
\hline & 80 & 80 & 0 \\
\hline \multirow[t]{2}{*}{5} & 100 & 100 & 0 \\
\hline & 80 & 80 & 0 \\
\hline \multirow[t]{2}{*}{6} & 100 & 100 & 0 \\
\hline & 80 & 80 & 0 \\
\hline \multirow[t]{2}{*}{7} & 102 & 100 & 1,96 \\
\hline & 82 & 80 & 2,5 \\
\hline \multirow[t]{2}{*}{8} & 100 & 100 & 0 \\
\hline & 79 & 80 & 1,25 \\
\hline \multirow[t]{2}{*}{9} & 99 & 100 & 1 \\
\hline & 80 & 80 & 0 \\
\hline \multicolumn{3}{|c|}{ Total Error } & 0,69 \\
\hline
\end{tabular}

Tabel 3 Merupakan hasil pengujian yang dilakukan dengan membandingkan sensor HC-SR04 dengan pengukuran manual. Hasil yang didapatkan cukup baik dengan rata-rata nilai error sebesar 0,69 $\%$. Hal ini bisa terjadi karena sensor HC-SR04 tidak tegak lurus atau bisa jadi objek yang ditangkap tidak tegak lurus.

\subsubsection{PengujianTeknis Jarak antar Jemah}

Pengujian ini dilakukan bertujuan untuk melihat apakah sensor jarak pada alat dapat berjalan dengan baik dan sesuai dengan yang diinginkan.

Tabel 4 Hasil Pengujian Teknis Jarak antar Jemaah

\begin{tabular}{|c|l|c|c|c|}
\hline \multirow{2}{*}{ No } & \multicolumn{2}{|c|}{ Pengujian } & \multicolumn{3}{|c|}{ Hasil Uji Coba } \\
\cline { 3 - 5 } & $\begin{array}{c}\text { Buzzer } \\
\text { Menyala }(\sqrt{ })\end{array}$ & $\begin{array}{c}\text { LED } \\
\text { Menyala }(\checkmark)\end{array}$ & Tampilan LCD \\
\hline 2 & Jarak 2 terisi & $\checkmark$ & $\checkmark$ & $\begin{array}{c}\text { Jarak 2 terisi, } \\
\text { pindah ke shaf 1 }\end{array}$ \\
\hline 2 & Jarak 2 tidak terisi & $\mathrm{x}$ & $\mathrm{x}$ & - \\
\hline 3 & $\begin{array}{l}\text { Jarak 4 terisi (shaf 1 } \\
\text { terisi) }\end{array}$ & $\checkmark$ & $\checkmark$ & $\begin{array}{c}\text { Jarak 4 terisi, } \\
\text { pindah ke shaf 2 }\end{array}$ \\
\hline 4 & Jarak 4 tidak terisi & $\mathrm{x}$ & $\mathrm{x}$ & - \\
\hline 5 & $\begin{array}{l}\text { Jarak 7 terisi } \\
\text { (kapasitas 9/9) }\end{array}$ & $\checkmark$ & $\checkmark$ & $\begin{array}{c}\text { Jarak 7 terisi, } \\
\text { mohon jaga jarak }\end{array}$ \\
\hline 6 & Jarak 7 tidak terisi & $\mathrm{x}$ & $\mathrm{x}$ & - \\
\hline
\end{tabular}

Tabel 4 diatas dapat dilihat bahwa saat Jemaah menempati jarak antar shaf maka buzzer berbunyi dan $L E D$ dapat menyala dengan baik. Tampilan pada $L C D$ memberikan informasi kepada Jemaah untuk pindah ke shaf lain selagi kapasitas Masjid belum penuh, namun jika kapasitas Masjid penuh maka $L C D$ menampilkan informasi untuk menjaga jarak antar shaf.

\subsubsection{PengujianTeknis Suhu Jemah}

Pengujian ini dilakukan bertujuan untuk melihat apakah sensor suhu pada alat dapat berjalan dengan baik dan sesuai dengan yang diinginkan.

Tabel 5 Hasil Pengujian Teknis Jarak antar Jemaah

\begin{tabular}{|c|l|c|}
\hline No & \multicolumn{1}{|c|}{ Pengujian } & Buzzer Menyala $(\checkmark)$ \\
\hline 1 & Suhu Jemaah $<36.0^{\circ} \mathrm{C}$ & $\mathrm{x}$ \\
\hline 2 & Suhu Jemaah $>=36.0^{\circ} \mathrm{C} \&<38^{\circ} \mathrm{C}$ & $\mathrm{x}$ \\
\hline 3 & Suhu Jemaah $>=38.0^{\circ} \mathrm{C}$ & $\checkmark$ \\
\hline
\end{tabular}

Tabel 5 diatas dapat dilihat bahwa saat Jemaah memiliki suhu tubuh dibawah $36^{\circ} \mathrm{C}$ maka buzzer tidak akan berbunyi, begitu pula saat Jemaah memiliki suhu tubuh normal berkisar $36^{\circ} \mathrm{C}$ sampai $37.9^{\circ} \mathrm{C}$. Buzzer akan menyala saat suhu Jemaah berada pada $38^{\circ} \mathrm{C}$ keatas yang menandakan bahwa Jemaah tersebut sedang kurang sehat dan dapat dihimbau agar dapat berisitirahat dan beribadah di rumah saja. 


\subsubsection{Pengujian User}

Pengujian ini dilakukan bertujuan untuk melihat apakah alat dapat berjalan dengan baik dan sesuai dengan yang diinginkan.

Tabel 6 Hasil Pengujian User

\begin{tabular}{|c|c|c|c|c|c|}
\hline \multirow[b]{2}{*}{ No } & \multirow[b]{2}{*}{ Pertanyaan } & \multicolumn{4}{|c|}{ Respon } \\
\hline & & $\begin{array}{l}\text { Sangat } \\
\text { Setuju }\end{array}$ & Setuju & $\begin{array}{c}\text { Kurang } \\
\text { Setuju }\end{array}$ & $\begin{array}{l}\text { Tidak } \\
\text { Setuju }\end{array}$ \\
\hline 1 & $\begin{array}{l}\text { Meningkatkan kepatuhan } \\
\text { protokol kesehatan di Masjid }\end{array}$ & 5 & 3 & 0 & 0 \\
\hline 2 & $\begin{array}{l}\text { Mengurangi kewaspadaan diri } \\
\text { saat melaksanakan ibadah di } \\
\text { Masjid }\end{array}$ & 5 & 2 & 1 & 0 \\
\hline 3 & $\begin{array}{l}\text { Mempermudah pengurus dalam } \\
\text { menjalankan protokol kesehatan } \\
\text { di Masjid }\end{array}$ & 5 & 3 & 0 & 0 \\
\hline & Total & 15 & 8 & 1 & 0 \\
\hline & Persentase & $62,5 \%$ & $33,3 \%$ & $4,17 \%$ & $0 \%$ \\
\hline
\end{tabular}

Tabel merupakan hasil dari pengujian user. Pengujian ini mendapatkan hasil yaitu sangat setuju sebesar $62,5 \%$ setuju $33,3 \%$ dan sisanya $4,17 \%$ kurang setuju.

\section{KESIMPULAN DAN SARAN}

\subsection{Kesimpulan}

Kesimpulan diambil dari hasil pengujian yang telah dilakukan pada bab 4. Kesimpulan berisikan hal - hal yang sifatnya terukur ( data angka, prosentase dll). Berikut contoh penulisan kesimpulan.

Berdasarkan beberapa pengujian yang telah dilakukan didapatkan kesimpulan :

1. Tingkat akurasi pada sensor suhu MLX90614 dapat membaca suhu dengan keakuratan 94,75 $\%$. Dengan tingkat keakuratan tersebut sensor dapat membaca suhu jemaah dengan cukup baik sesuai dengan protokol kesehatan.

2. Tingkat akurasi pada sensor jarak HC-SR04 dapat membaca jarak dengan keakuratan 99,31\%. Dengan tingkat keakuratan tersebut sensor dapat membaca jarak yang harus dijaga antar shaf bagi para jemaah yang beribadah di Masjid

3. Pengujian user mendapatkan respon yang cukup baik sehingga tujuan dari penilitan ini dianggap tercapai. Hal ini terbukti dengan rata-rata sangat setuju sebesar $62,5 \%$ dan $33,3 \%$ setuju, sedangkan sisanya sebesar $4,17 \%$ mengatakan kurang setuju.

4. Berdasarkan hasil pengujian user, sistem monitoring jarak dan suhu di Masjid berbasis IoT dapat membantu pengurus Masjid dalam menjalankan protokol kesehatan.

5. Berdasarkan hasil pengujian user, sistem peringatan terhadap jemaah dapat menjaga kepatuhan jemaah dalam menjalankan ibada di Masjid sesuai protokol kesehatan.

6. Berdasarkan hasil pengujian teknis, sistem peringatan terhadap jemaah sesuai protokol kesehatan dapat berjalan secara otomatis dengan baik.

\subsection{Saran}

Saran berisikan hal - hal apa yang harus diperbaiki dari aplikasi dan metode yang anda buat untuk pengembangan lebih lanjut dengan tujuan agar hasil yang dicapai lebih maksimum. Saran harus dituliskan secara tegas, lugas dan tidak boleh ambigu. Berikut contoh penulisan sara

Berdasarkan penelitian yang telah dilakukan, maka penulis dapat memberikan saran-saran untuk pengembangan selanjutnya antar lain :

1. Model sensor MLX90614 yang digunakan dapat mendeteksi suhu pada object dengan cukup baik. Sensor MLX90614 dapat digantikan dengan sensor suhu thermal akan lebih baik menggunakan model sensor MLX90614 DCI $5^{\circ}$ atau model sensor MLX90614 dengan FOV (field of view) yang lebih besar.

2. Sensor ultrasonic HC-SR04 dapat mendeteksi jarak dengan baik. Sensor HC-SR04 dapat diganti dengan sensor jarak yang lebih baik lagi seperti GY-US42 atau VL53L0X dengan tingkat keakuratan lebih tinggi serta tidak membutuhkan space yang besar.

\section{DAFTAR PUSTAKA}

[1] Who.int. Tanpa tahun. Pertanyaan dan jawaban terkait Coronavirus. Diakses pada 4 September 2020 , dari https://www.who.int/indonesia/news/novelcoronavirus/qa/qa-for-public

[2] Rs-jih.co.id. 22 Juni 2020. Bersiap Menghadapi New Normal Dengan Protokol Kesehatan. Diakses pada 4 September 2020, dari https://rsjih.co.id/readmore/bersiap-menghadapi-newnormal-dengan-protokol-kesehatan

[3] Rosmha Widiyani. 13 Maret 2020. Gara-Gara Virus Corona, Begini Sholat Jumat di Arab dan Negara Lain. Diakses pada 4 September 2020, dari https://news.detik.com/berita/d4937567/gara-gara-virus-corona-begini-sholatjumat-di-arab-dan-negara-lain

[4] Ridwan, Nur Muhammad. "Rancang Bangun Sistem Monitoring Tempat Parkir Berbasis Arduino". JATI, Vol. 1 Maret 2017.

[5] Arsada, Bakhtiyar. "Aplikasi Sensor Ultrasonik Untuk Deteksi Posisi Jarak Pada Ruang Menggunakan Arduino Uno". Jurnal Teknik Elektro. Volume 06 Nomor 02 Tahun 2017, 137 - 145 .

[6] Sollu, Tan Suryani. dkk. "Sistem Monitoring Detak Jantung dan Suhu Tubuh Menggunakan Arduino". Vol. 17, No. 3, Agustus 2018 : 323332.

[7] Joseph Dedy Irawan, Fourry Handoko, Emmalia Adriantatri, Suryo Adi Wibowo, Yosep Agus Pranoto. "uang Kuliah Pintar Pemantau Tingkat Efektivitas Pembelajaran Yang Dapat Mendeteksi Mahasiswa Bosan Dan Mengantuk". 2 Februari 2019. 
[8] Lab Elektronika. (27 Februari 2017). Arduino Mega 2560 Mikrocontroller ATMega2560. Diakses pada 4 Desember 2020, dari http://www.labelektronika.com/2017/02/arduinomega-2560-mikrokontroler.html

[9] Embeddednesia.com. (19 April 2017). Mengenal NodeMCU : Pertemuan Pertama. Diakses pada 4 September 2020, dari https://embeddednesia.com/v1/tutorial-nodemcupertemuan-pertama/

[10] Aldy Razor. (14 Mei 2020). Push Button Arduino : Pengertian, Fungsi, dan Prinsip Kerja. Diakses pada 5 Desember 2020, dari https://www.aldyrazor.com/2020/05/pushbutton-arduino.html
[11]Elangsakti.com. (Mei 2015). Cara Kerja Sensor Ultrasonik, Rangkaian, \& Aplikasinya. Diakses pada 4 September 2020, dari https://www.elangsakti.com/2015/05/sensorultrasonik.html

[12] Sinaupedia.com. (18 Januari 2020). 28BYJ-48 Pengertian Motor Servo. Diakses pada 5 Desember 2020, dari https://sinaupedia.com/pengertian-motor-servo/

[13] Embeddednesia.com. (23 Desember 20180. Bermain dengan Sensor Suhu Nirsentuh MLX90614. Diakses pada 4 September 2020, dari https://embeddednesia.com/v1/bermaindengan-sensor-suhu-nirsentuh-mlx 90614. 